\begin{tabular}{|c|c|c|}
\hline Dinamika Journal, Vol. 1 No. 4, 2019 \\
ISSN ONLINE : 2686-2158
\end{tabular}

\title{
PENGEMBANGAN KAPASITAS PENYULUHAN BERBASIS MASYARAKAT BERPERSPEKTIF GENDER DALAM MENINGKATKAN KETAHANAN KELUARGA DI KECAMATAN SUMBANG, KABUPATEN BANYUMAS
}

\author{
Dyah Retna Puspita $^{\left.1^{*}\right)}$, Wahyuningrat ${ }^{1)}$, Pawrtha Dharma ${ }^{1)}$, Alizar Isna ${ }^{1)}$ \\ ${ }^{1}$ Fakultas Ilmu Sosial dan Ilmu Politik, Universitas Jenderal Soedirman, Purwokerto, \\ Indonesia \\ *Corresponding author: dyah.puspita@unsoed.ac.id
}

Received 4 November 2019; Accepted 27 November 2019; Available online 4 December 2019

\begin{abstract}
Abstrak
Banyaknya kasus perceraian dan keluarga "rawan cerai" di Kecamatan Sumbang menuntut peranserta yang lebih besar dari organisasi Pemberdayaan dan Kesejahteraan Keluarga (PKK) di kecamatan ini untuk mencegahnya, antara lain melalui kegiatan penyuluhan. Dalam kenyataannya, tingkat kemampuan para pengurus organisasinya baik di tingkat kecamatan maupun desa untuk melakukan penyuluhan yang sesuai dengan permasalahan kebutuhan komunitas setempat masih rendah. Untuk itu dilakukan upaya peningkatan kapasitas kepada mereka melalui kegiatan pelatihan sehari. Sasarannya adalah 24 orang yang terdiri dari Pengurus PKK Kecamatan Pokja I dan Ketua PKK Desa di semua desa. Metodenya adalah pemberian empat materi yang dibutuhkan yakni: (1) Peran strategis PKK dalam Pemberdayaan Keluarga dan Peningkatan Ketahanan Keluarga, (2) Pembangunan Keluarga dan Ketahanan Keluarga, (3) Fenomena Perceraian di Kecamatan Sumbang, serta (4) Penyuluhan Berbasis Komunitas Berperspektif Gender. Pemberian materi dilakukan secara interaktif melalui teknik ceramah dan diskusi yang diakhiri dengan pendampingan pembuatan Rencana Tindak lanjut (RTL). Evaluasi diberikan dengan memberikan sejumlah pertanyaan/pernyataan untuk masing-masing materi melalui teknik pre-test dan post-test yakni pengisian sebelum dan setelah pemnberian materi. Dengan teknik ini diketahui adanya peningkatan pengetahuan yang diterima setelah pemberian materi dari ke-4 materi tersebut. Diketahui pula adanya peningkatan sensitivitas gender melalui RTL yang dibuat yang tidak hanya menyertakan kelompok perempuan/istri sebagai sasaran penyuluhan ketahanan keluargannya, melainkan juga kelompok laki-laki melalui forum RT/RW dan Karang Taruna.
\end{abstract}

Kata kunci: penyuluhan PKK, ketahanan keluarga, perceraian, penyuluhan gender

\section{Abstract}

The many cases of divorce and "divorce-prone" families in Sumbang sub-district demand greater participation from the Empowerment and Family Welfare (PKK) organization in this sub-district to prevent them, among others through counseling activities. In reality, the level of ability of the organizers of the organization, both at the sub-district and village levels, to conduct counseling in accordance with the problems of local community needs is still low. That is why a day's training activities are carried out to increase their capacity. The target is 24 people consisting of PKK Administrators of Pokja I Sub-District and Village PKK Chairpersons in all villages. The method is the provision of four materials needed, namely: (1) PKK's strategic role in Family Empowerment and Family Resilience Enhancement, (2) 
Family Development and Family Resilience, (3) Divorce Phenomena in Sumbang District, and (4) Community-Based Counseling with Gender Perspective. The material was given interactively through lecture and discussion techniques which ended with assistance in making the Follow-up Plan (RTL). Evaluation is given by giving a number of questions / statements for each material through pre-test and post-test techniques, namely filling before and after giving the material. With this technique it is known that there is an increase in knowledge received after giving material from the 4 materials. It is also known that there has been an increase in gender sensitivity through RTLs which are made not only to include women / wives groups as targets for counseling family resilience, but also groups of men through RT / RW and Karang Taruna forums.

Keywords: PKK counseling, family resilience, divorce, gender counseling

\section{Pendahuluan}

\section{Latar Belakang/Permasalahan}

Beberapa tahun terakhir ini terjadi peningkatan kasus perceraian di hampir semua wilayah di Indonesia. Jika pada tahun 2013 jumlahnya adalah sebanyak 324.247 kasus, maka tahun 2014 meningkat menjadi 344.237 dan naik lagi menjadi 347.256 kasus di tahun 2015. Jawa Tengah menempati urutan kedua setelah Jawa Timur. Tahun 2013 jumlahnya 85.484 kasus, meningkat menjadi 89.406 kasus dan sedikit menurun di tahun 2015 menjadi 87.149 kasus (BPS, 2018).

Salah satu penyumbang terbesarnya adalah Kabupaten Banyumas yang memiliki dua Pengadilan Agama yakni Pengadilan Agama (PA) Banyumas dan PA Purwokerto. Tahun 2017 jumlahnya mencapai 4.181 kasus menduduki urutan ketiga atau 5,84 persen dari total Jawa Tengah (BPS Jawa Tengah, 2018).

Kecamatan Sumbang yang berada tidak jauh dari Universitas Jenderal Soedirman menjadi salah satu kecamatan dengan kasus perceraian yang tinggi. Bahkan tahun 20112015 jumlah kasusnya hampir selalu terbanyak di Kabupaten Banyumas dan tahun 2015 jumlahnya terbanyak. Jika diperbandingkan dengan jumlah nikah dan rujuk yang terjadi pada tahun tersebut, maka persentase perceraian (mencakup Cerai dan Talak) tahun 2015 adalah yang tertinggi yakni 27,54 persen. Di setiap tahunnya kasus perceraian selalu didominasi oleh Gugat (disebut juga cerai gugat) yang berarti pemohon perceraiannya adalah istri.

Tabel 1. Jumlah Perceraian di Kecamatan Sumbang Tahun 2011 - 2015

\begin{tabular}{|c|c|c|c|c|c|c|c|c|}
\hline \multirow{2}{*}{ Tahun } & \multirow{2}{*}{ Nikah } & \multirow{2}{*}{ Rujuk } & \multicolumn{4}{|c|}{ Jenis Perceraian } & \multirow{2}{*}{$\begin{array}{l}\text { Peringkat } \\
\text { Perceraian } \\
\text { se- } \\
\text { kabupaten }\end{array}$} & \multirow{2}{*}{$\begin{array}{c}(4+5) / \\
(2+3) * 100\end{array}$} \\
\hline & & & Talak & Gugat & Total & $\%$ Gugat & & \\
\hline-1 & -2 & -3 & -4 & -5 & -6 & -7 & -8 & -9 \\
\hline $2011^{1}$ & 890 & 0 & 36 & 78 & 114 & 68,42 & 1 & 12,81 \\
\hline $2012^{2}$ & 884 & 1 & 33 & 90 & 123 & 73,17 & 2 & 13,9 \\
\hline $2013^{3}$ & 909 & 0 & 40 & 76 & 116 & 65,52 & 2 & 12,76 \\
\hline $2014^{4}$ & 896 & 0 & 55 & 63 & 118 & 53,39 & 1 & 13,17 \\
\hline $2015^{5}$ & 708 & 0 & 42 & 153 & 195 & 78,46 & 1 & 27,54 \\
\hline
\end{tabular}

Sumber: ${ }^{1}$ BPS Kabupaten Banyumas, 2012; ${ }^{2}$ BPS Kabupaten Banyumas, 2013; ${ }^{3}$ BPS Kabupaten Banyumas, 2014; ${ }^{4}$ BPS Kabupaten Banyumas, 2015; ${ }^{5}$ BPS Kabupaten Banyumas, 2016 
Banyak dari pasangan bercerai tersebut adalah pasangan muda. Data Kantor Urusan Agama (KUA) Kecamatan Sumbang menunjukkan bahwa tahun 2015, dari 193 pasangan yang sudah diputus cerai oleh Pengadilan Agama Banyumas, sekitar sepertiganya adalah mereka yang berumur 20-30 tahun dengan masa pernikahan 0-5 tahun. Mayoritas penyebabnya adalah karena masalah ekonomi, perselisihan dan ketidakharmonisan (KUA Kecamatan Sumbang, 2015).

Meskipun tahun 2016 jumlah perceraian di Kecamatan Sumbang "hanya" 110 kasus dan menduduki peringkat kelima (BPS Kabupaten Banyumas, 2017) dan turun lagi menjadi 96 kasus di tahun 2017 (BPS Kabupaten Banyumas, 2018), akan tetapi kecamatan ini masih termasuk wilayah yang "rawan cerai". Hal ini disebabkan faktor terbanyak penyebabnya adalah masalah ekonomi, karena tingginya tingkat kemiskinan. Pada tahun 2014 hampir sepertiga keluarganya (26,26 persen) termasuk keluarga Pra Sejahtera (BPS Kabupaten Banyumas, 2015). Hingga tahun 2017 jumlahnya bahkan sedikit meningkat menjadi 26,32 persen (BPS Kabupaten Banyumas, 2018).

Banyaknya perceraian (terutama gugat cerai oleh istri) di Kecamatan Sumbang yang sudah berlangsung lama yang kebanyakan adalah pasangan muda tersebut perlu diupayakan solusinya mengingat dampaknya yang luas dan multidimensi, terutama bagi anak. Hal ini dirasakan oleh para Guru Bimbingan Konseling (BP) SMP di wilayah ini yang merasakan adanya kenaikan jumlah anak bermasalah di sekolah terutama dari keluarga tidak harmonis dan bercerai (wawancara dengan Ketua Persatuan Guru Bimbingan Konseling/BP SMP Rayon 2 Kabupaten Banyumas di mana Kecamatan Sumbang termasuk di dalamnya).

Salah satu lembaga sosial yang sangat berperan dalam pemberdayaan keluarga adalah organisasi Pemberdayaan dan Kesejahteraan Keluarga (PKK). Hal ini disebabkan jaringannya yang sangat luas hingga ke tingkat Rukun Tetangga (RT) dan bahkan Dasa Wisma (kelompok10-an keluarga). Visinya adalah Terwujudnya keluarga yang beriman dan bertakwa kepada Tuhan yang Maha Esa, berakhlak mulia dan berbudi luhur, sehat sejahtera, lahir batin (http://pkk.semarangkota.go.id/pages/visi-misi).

Di samping itu, PKK juga mendapat dukungan sangat kuat dari Pemerintah. Pasal 9 Keputusan Menteri Dalam Negeri dan Otonomi Daerah RI Nomor 53 Tahun 2000 tentang Gerakan Pemberdayaan dan Kesejahteraan Keluarga menyebutkan bahwa Ketua Tim Penggerak/TP di tingkat Provinsi, Kabupaten/Kota dan Kecamatan adalah istri Gubernur, istri Bupati/Walikota dan Istri Camat (kecuali jika Gubernur, Bupati/Walikota dan Camat adalah perempuan, maka Ketua TP PKK ditunjuk oleh pejabat yang bersangkutan).

\section{Perumusan Masalah}

Kegiatan PKK Kecamatan Sumbang digerakkan oleh pengurus (disebut Tim Penggerak/TP) yang terdiri dari empat Kelompok Kerja (Pokja). Salah satunya adalah Pojka I yang membidangi Ketahanan Keluarga. Kegiatan rutin TP PKK Kecamatan adalah mengadakan pertemuan bulanan dengan perwakilan PKK Desa se-Kecamatan Sumbang yang berjumlah 19 desa. Dalam kegiatan tersebut disampaikan materi-materi baik yang diberikan oleh PKK Kabupaten baik berupa informasi kegiatan maupun materi penyuluhan yang diminta untuk diteruskan kepada pengurus dan anggota PKK di tingkat Rukun Warga (RW) dan Rukun Tetangga (RT).

Seiring dengan penurunan ketahanan keluarga yang sedang terjadi di wilayah Kecamatan Sumbang, maka kegiatan Pokja I menjadi sangat menentukan dalam upaya pencegahan perceraian dan penanganan keluarga-keluarga yang bercerai. Dalam kenyataannya, hingga tahun 2018 tidak ada kegiatan yang terkait dengan hal tersebut sebagaimana disampaikan Sekretaris PKK Kecamatan Sumbang (wawancara 14 April 2019). Informasi yang disampaikan masih sebatas informasi hasil pertemuan di tingkat Kabupaten 
yang juga tidak menyinggung tentang hal tersebut. Padahal, meskipun merupakan organisasi hirarkhis, akan tetapi masing-masing TP PKK Kecamatan mempunyai "peluang" untuk menambahkan informasi yang terkait dengan permasalahan yang aktual di masing-masing kecamatan.

Tidak adanya informasi tentang penurunan ketahanan keluarga menunjukkan bahwa kegiatan penyuluhan PKK di Kecamatan Sumbang belum "membumi" atau belum berbasis pada permasalahan komunitas keluarga setempat. Di samping itu, penyuluhannya selama inipun masih bias gender, karena hanya ditujukan bagi kaum perempuan/istri. Padahal, keluarga terdiri dari perempuan/istri dan laki-laki/suami di mana keduanya mempunyai hak dan kebutuhan untuk mendapatkan informasi yang terkait dengan permasalahan keluarga guna mewujudkan keluarga berkualitas.

Dari uraian di atas dapatlah dirangkum bahwa permasalahan yang dialami Pokja I PKK baik di tingkat kecamatan maupun desa adalah: (1) belum diterapkannya penyuluhan ketahanan keluarga yang berbasis pada permasalahan dan kebutuhan masyarakat (terutama keluarga-keluarga) di wilayah mereka serta (2) belum digunakannya perspektif gender dalam penyuluhan mereka. Sehubungan dengan hal ini, maka rumusan masalahnya adalah: Bagaimana upaya meningkatkan kapasitas penyuluhan ketahanan keluarga bagi para Pengurus PKK Kecamatan Sumbang agar lebih berbasis pada permasalahan dan kebutuhan masyarakat setempat serta lebih sensitif gender?

\section{Urgensi}

Upaya meningkatkan kapasitas penyuluhan ketahanan keluarga dari para Pengurus PKK Kecamatan perlu dilakukan Karen merekalah yang menjadi ujung tombak organisasi PKK di wilayahnya. Dengan sifat organisasinya yang hirarkhis, maka kebijakan di tingkat kecamatan akan diikuti oleh PKK di tingkat desa untuk selanjutnya ke seluruh keluarga di wilayah desa masing-masing. Dengan menurunnya ketahanan keluarga, maka Pokja I baik di tingkat kecamatan maupun Desa harus lebih peka terhadap permasalahan ini dan mampu membuat kegiatan penyuluhan yang berupaya untuk mencegah dan menanganinya.

Pelibatan PKK Desa dalam proses pelatihan tersebut (yang dalam hal ini diwakili oleh Ketua PKK Desa) disebabkan kebanyakan dari mereka adalah "wajah baru" di mana mereka secara "otomatis" menjadi Ketua PKK Desa setelah suami mereka dilantik menjadi Kepala Desa dalam proses pemilihan Kepala Desa Serentak di Kabupaten Banyumas pada bulan Mei 2019. Untuk itu kapasitas mereka juga perlu diperkuat.

\section{Rasionalisasi kegiatan}

Upaya peningkatan kapasitas ini dikemas melalui wadah kegiatan Pelatihan Peningkatan Kapasitas Penyuluhan Ketahanan Keluarga Berbasis Komunitas Berperspektif Gender. Bentuk kegiatannya adalah berupa pelatihan karena teknik penyampaiannya berupa ceramah dan diskusi/tanya jawab. Dengan demikian, dapat terjadi interaksi yang lebih intensif di antara pemberi materi dengan para peserta yang hanya berjumlah 24 orang. Untuk memperjelas informasi perubahan pengetahuan yang terjadi, dilakukan pre-test dan post-test.

\section{Tujuan kegiatan}

Kegiatan yang ditujukan bagi Pengurus Pokja I PKK Kecamatan Sumbang dan Ketua PKK Desa se-kecamatan Sumbang ini bertujuan untuk meningkatkan pengetahuan mereka tentang: (1) peran strategis PKK dalam upaya peningkatan ketahanan keluarga dan pencegahan perceraian, (2) urgensi pembangunan keluarga dan ketahanan keluarga dalam pencegahan perceraian dan (3) fenomena perceraian di Kecamatan Sumbang beserta faktor penyebab dan dampaknya serta (4) meningkatkan pengetahuan dan keterampilan mereka dalam melaksanakan penyuluhan ketahanan keluarga yang berbasis pada kebutuhan dan permasalahan masyarakat/keluarga setempat serta berperspektif gender. 


\section{Rencana pemecahan masalah}

Kondisi rendahnya tingkat pengetahuan dan keterampilan para Pengurus Pokja I PKK Kecamatan Sumbang dan Desa dalam penyuluhan ketahanan keluarga yang berbasis masyarakat berperspektif gender yang telah dijelaskan di atas dapat diatasi dengan beberapa cara. Cara pertama misalnya dengan memberikan buku-buku dan materi pendukung yang diminta untuk dipelajari sendiri. Cara kedua adalah dengan memberikan pelatihan.

Cara pertama (pemberian buku) dianggap kurang efektif karena memiliki sejumlah kelemahan yakni: (a) kebanyakan dari mereka adalah pekerja (ASN), sehingga dikhawatirkan tidak mempunyai waktu untuk mempelajarinya secara mandiri, (b) budaya membaca di kalangan masyarakat (terutama kalangan menengah ke bawah) pada umumnya masih rendah, dan (3) belum ada satu buku yang mampu merangkum semua materi yang dibutuhkan, sehingga terlalu banyak buku yang harus dibaca.

Adapun cara kedua yang berupa pemberian pelatihan dengan empat materi merupakan cara yang paling efektif karena: pertama, diberikan oleh para pakar dengan metode ceramah yang dilanjutkan dengan tanya jawab dan diskusi. Dengan demikian, para peserta akan mendapatkan informasi yang jelas dan mendalam. Kedua, digunakannya $L C D$ sebagai alat bantu ceramah yang menampilkan powerpoint materi yang dibuat ilustratif akan lebih memudahkan peserta menangkap materi yang disampaikan. Ketiga, target capaiannya yang tidak hanya meningkatkan pengetahuan, melainkan juga sikap dan keterampilan, akan lebih memacu peserta mampu merancang rencana kegiatan penyuluhan yang benar-benar berbasis pada permasalahan keluarga setempat dan berperspektif gender. Keempat, waktu pelaksanaannya yang tidak terlalu lama yakni 7 jam (jam $9.00-16.00$ ) adalah sesuai dengan kemampuan daya serap mereka.

\section{METODE PELAKSANAAN}

Upaya peningkatan kapasitas para Pengurus Pokja I Kecamatan dan Desa ini ditempuh melalui kegiatan pelatihan selama satu hari selama tujuh jam dari pukul 09.0016.00. Jumlah pesertanya adalah sebanyak 25 orang yang terdiri dari 6 orang dari Pokja I PKK Kecamatan dan 19 orang Pokja I PKK Desa (diwakili oleh Ketua). Materi yang diberikan adalah sebanyak empat materi yang terdiri dari: (1) Peran Strategis PKK dalam Pencegahan Perceraian, (2) Pembangunan Keluarga dan Ketahanan Keluarga, (3) Fenomena Perceraian di Kecamatan Sumbang, serta (4) Penyuluhan Berbasis Komunitas Berperspektif Gender. Metode pelatihannya adalah berupa: ceramah dan tanya jawab, analisis faktor-faktor penyebab perceraian di Kecamatan Sumbang serta praktek pembuatan rencana tindak lanjut (RTL) tentang kegiatan penyuluhan ketahanan keluarga berbasis masyarakat berperspektif gender yang akan dilaksanakan setelah mengikuti kegiatan pelatihan.

Untuk mengetahui perubahan pengetahuan yang dimiliki antara sebelum dan setelah mengikuti pelatihan, digunakan teknik pre-test dan post-test. Teknik ini adalah berupa pemberian sejumlah pertanyaan (dalam bentuk pernyataan) yang terkait dengan masingmasing materi yang diminta dijawab oleh peserta sebelum pemberian materi (pre-test) dan setelah pemberian materi (post-test). Selanjutnya, untuk mengukur ada tidaknya perbedaan kondisi sebelum dan sesudah pelatihan, digunakan teknik uji beda dengan menggunakan uji t. Adapun untuk mengevaluasi keterampilan dalam membuat rancangan penyuluhan yang berbasis masyarakat dan berperspektif gender, dilakukan dengan cara menilai Rancangan Tindak Lanjut (RTL) yang mereka buat. Aspek-aspek yang dinilai adalah pada ketepatan dan ketajaman penentuan sasaran, metode dan teknik penyuluhan yang dibuat. 


\section{HASIL DAN PEMBAHASAN}

\section{Gambaran Umum PKK Kecamatan Sumbang}

PKK Kecamatan Sumbang merupakan bagian dari PKK Kabupaten Banyumas yang berlokasi di kantor Kecamatan Sumbang (sekitar 3,5 kilometer dari kampus Universitas Jenderal Soedirman). Organisasi yang diketuai istri Camat ini mencakupi 19 PKK Desa yang dibagi menjadi 78 PKK RW dan 441 PKK RT. Wilayah ini didiami 20.385 keluarga dengan rata-rata anggota rumah tangganya sebanyak 4,0 yang artinya rata-rata jumlah anaknya adalah 2 anak. Kebanyakan warganya bekerja di bidang pertanian (32,13 persen) dan perdagangan (21,85 persen) (BPS Kabupaten Banyumas, 2017).

Pada tahun 2018 prioritas program kerja PKK Kecamatan Sumbang adalah peningkatan sumberdaya manusia agar menjadi maju dan mandiri dengan kemantapan kelembagakan, memberikan tambahan bekal pengetahuan, bimbingan, pengembangan dan penggerakan potensi yang ada untuk menuju ke arah kemandirian keluarga (Tim Penggerak PKK Kecamatan Sumbang, 2018). Dalam kenyataannya, pada Laporan Program Kerja 2018 tidak disinggung tentang fenomena maraknya perceraian di kecamatan ini serta tidak ada kegiatan penyuluhan ketahanan keluarga yang menekankan pada upaya pencegahan perceraian. Materi penyuluhannya baru sebatas pencegahan Kekerasan dalam Rumah Tangga (KDRT) dan materi lainnya sebagaimana yang disampaikan Pengurus PKK Kabupaten.

\section{Profil Peserta}

Peserta Penyuluhan Ketahanan Keluarga Berbasis Komunitas Berperspektif Gender Kecamatan Sumbang berjumlah 25 orang, dengan peserta laki-laki hanya satu orang (4 persen). Apabila dilihat dari unsur atau tingkatan organisasi PKKnya, 6 orang dari PKK kecamatan dan 19 orang lainnya dari PKK desa. Peserta dari PKK kecamatan terdiri atas Ketua PKK Kecamatan (istri Camat Sumbang), Sekretaris dan 4 orang pengurus Pokja I (Ketahanan Keluarga). Sedangkan peserta dari PKK desa, hampir seluruhnya diwakili oleh ketua PKK desa atau isteri kepala desa. Para isteri kepala desa tersebut, umumnya merupakan ketua PKK desa yang baru karena suaminya memenangkan pemilihan kepala desa.

Dilihat dari karakteristik usia, paling banyak (48 persen) adalah dari kelompok usia 50-59 tahun. Kelompok usia dengan jumlah relatif besar berikutnya pada rentang usia 40-49 tahun sebesar 28 persen. Menariknya, masih ada pengurus PKK yang berusia lebih dari 60 tahun meski hanya 4 persen.

Walaupun relatif kecil (28 persen) pendidikan sarjana menempati jumlah paling banyak, diikuti pendidikan SMA/sederajat (0,24 persen), dan SD/sederajat (0,2 persen). Relatif banyaknya Tim Penggerak (TP) PKK yang berpendidikan sarjana, memberikan harapan akan kemampuan mereka untuk melaksanakan 10 program pokok PKK sebagai upaya pemenuhan kebutuhan dasar untuk terwujudnya pemberdayaan dan kesejahteraan keluarga. Gambaran profil peserta selengkapnya, dapat dilihat pada tabel 2 berikut. 
Tabel 2. Karakteristik peserta penyuluhan ketahanan keluarga berbasis komunitas berperspektif gender

\begin{tabular}{cccccccccc}
\hline \multicolumn{2}{c}{ Karakteristik Peserta } & \multicolumn{7}{c}{ Pendidikan } & Jumlah \\
\cline { 1 - 6 } $\begin{array}{c}\text { Jenis } \\
\text { Kelamin }\end{array}$ & Unsur & $\begin{array}{c}\text { Usia } \\
\text { (Tahun) }\end{array}$ & SD & SMP & SMA & D-3 & S-1 & NA & \\
\hline Perempuan & $\begin{array}{c}\text { PKK } \\
\text { Kecamatan }\end{array}$ & $50-59$ & 0 & 0 & 1 & 0 & 3 & 1 & 5 \\
Laki-laki & & $50-59$ & 0 & 0 & 0 & 1 & 0 & 0 & 1 \\
& & $30-39$ & 1 & 1 & 0 & 0 & 0 & 0 & 2 \\
Perempuan & PKK Desa & $40-49$ & 0 & 1 & 4 & 1 & 1 & 0 & 7 \\
& & $50-59$ & 2 & 1 & 1 & 0 & 2 & 0 & 6 \\
& & NA & 0 & 1 & 0 & 0 & 0 & 0 & 1 \\
\hline
\end{tabular}

Sumber: Data Primer, Diolah

Keterangan: NA = No Answer (Tidak Menjawab)

\section{Penyampaian Materi/Pelaksanaan Kegiatan}

Kegiatan pelatihan ini diisi dengan pemberian empat materi yang perlu dimiliki agar dapat memberikan penyuluhan yang berbasis permasalahan dan kebutuhan keluarga setempat serta tidak bias gender. Materi pertama adalah "Urgensi Keterlibatan PKK dalam Pencegahan Perceraian”. Materi ini menegaskan posisi strategis PKK sebagai organisasi pemberdayaan keluarga terbesar dan terluas jaringannya di Indonesia. Posisi ini membuat PKK memiliki peran strategis dalam upaya pencegahan perceraian. Dalam struktur organisasinya, upaya ini merupakan salah satu penjabaran tugas dari Kelompok Kerja (Pokja) I yakni bidang Ketahanan Keluarga.

Materi kedua adalah "Pembangunan Keluarga dan Ketahanan Keluarga". Materi ini diberikan untuk semakin memantapkan pemahaman peserta bahwa pembangunan keluarga merupakan salah satu amanah Negara yang perlu terus dilaksanakan. Pembangunan ini semakin perlu diperhatikan seiring dengan menurunnya kondisi ketahanan keluarga di banyak daerah yang ditandai oleh banyaknya kasus perceraian. Menurut pasal 1 ayat 11 Undangundang Nomor 52 Tahun 2009 tentang Perkembangan Kependudukan dan Pembangunan Keluarga, "ketahanan dan kesejahteraan keluarga adalah kondisi keluarga yang memiliki keuletan dan ketangguhan serta mengandung kemampuan fisik-materiil guna hidup mandiri dan mengembangkan diri dan keluarga untuk hidup harmonis dalam meningkatkan kesejahteraan kebahagiaan lahir batin”. Pilar ketahanan keluarga mencakup ketahanan secara fisik, psikologis dan sosial (Sunarti dalam Puspitawati, 2008). Ketahanan fisik adalah apabila terpenuhi kebutuhan pangan, sandang, perumahan, pendidikan dan kesehatan. Ketahanan sosial adalah apabila keluarga tersebut berorientasi pada nilai agama, adanya komunikasi yang efektif di antara anggota keluarga serta adanya pembagian kerja. Adapun ketahanan psikologis keluarga adalah apabila keluarga mampu menanggulangi masalah nonfisik, mampu mengendalian emosi secara positif dan memiliki konsep diri positif (termasuk terhadap harapan dan kepuasan). Tidak berjalannya salah satu atau beberapa unsur tersebut akan memunculkan gangguan keharmonisan keluarga, terutama antara suami dan istri. Dampak paling parah dari kondisi ini adalah berakhirnya ikatan perkawinan yang disebut dengan perceraian.

Materi ketiga adalah "Fenomena Perceraian di Kecamatan Sumbang". Perceraian adalah terputusnya ikatan perkawinan yang dapat disebabkan banyak faktor. Hasil kajian di 
beberapa tempat antara lain di Jepang (Uchida, dkk., 1993), Amerika (J. Hardie \& Lucas, 2010) dan Iran (Maysam Musai et al, 2014) menegaskan bahwa faktor ekonomi berupa pendapatan yang rendah merupakan salah satu faktor penyebab perceraian. Kajian Hardie \& Lucas (2010) lebih memperjelas fenomenanya pada perceraian di kalangan pasangan muda. Fenomena ini pula yang banyak terjadi di Indonesia sebagaimana ditemukan dari beberapa hasil penelitian antara lain Matondang (2014), Muchimah (2015), Puspita, dkk. (2014) dan Puspita, dkk. (2017). Faktor ekonomi pula yang banyak menjadi penyebab putusnya perkawinan di Kecamatan Sumbang, Kabupaten Banyumas. Meskipun sejak tahun 2015 jumlah kasusnya menurun, akan tetapi masih banyak keluarga yang termasuk kategori "rawan cerai" disebabkan banyaknya laki-laki yang bekerja tidak tetap/serabutan.

Materi keempat adalah "Penyuluhan Ketahanan Keluarga Berbasis Komunitas Berperspektif Gender". Materi ini menjelaskan bahwa penyuluhan adalah upaya mengubah perilaku seseorang/sekelompok orang baik dari aspek pengetahuan, sikap maupun keterampilan/tindakan. Dengan demikian, penyuluhan ketahanan keluarga adalah upaya untuk meningkatkan keberdayaan keluarga melalui peningkatan ketiga aspek tersebut dengan maksud agar terwujud keluarga yang kokoh baik secara fisik, psikologis, maupun sosial. Penyuluhan tersebut perlu dilaksanakan dengan mendasarkan

Untuk menilai keberhasilan kegiatan pelatihan ini, telah dilakukan pre test dan post test terhadap materi-materi yang disangkuman yang dirangkum dalam 10 pernyataan. Materi pertama tentang "Urgensi PKK dalam Pencegahan Perceraian" diwakili oleh 2 pernyataan yakni: (1) UU Nomor 52 Tahun 2009 adalah UU peraturan tentang Perkembangan Kependudukan dan Pembangunan Keluarga, serta (2) Penyuluhan tentang perceraian menjadi salah tugas dari Pokja I.

Materi kedua ("Fenomena Perceraian di Kecamatan Sumbang") diwakili oleh 6 pernyataan yakni: (1) Jumlah perceraian di Kabupaten Banyumas tahun 2015 adalah yang terbanyak kedua di Jawa Tengah setelah Cilacap, (2) Jumlah kasus perceraian di Kecamatan Sumbang termasuh yang terbanyak di Kabupaten Banyumas, serta (3) Kantor Pengadilan Agama (PA) di Kabupaten Banyumas ada 2 yakni PA Banyumas dan PA Purwokerto, (4) Kebanyakan kasus perceraian di banyak daerah (termasuk di Kecamatan Sumbang) adalah berupa cerai gugat, (5) Kebanyakan perceraian saat ini disebabkan karena masalah ekonomi dan ketidakharmonisan" serta (6) Perceraian yang bersifat massif/ banyak tidak hanya merugikan keluarga tersebut, melainkan juga masyarakat dan bahkan Pemerintah. Adapun untuk materi ketiga yakni "Penyuluhan berbasis komunitas berperspektif gender" diwakili oleh 2 pernyataan yakni: (1) Penyuluhan keluarga berbasis komunitas adalah penyuluhan yang mendasarkan materi dan metodenya kepada permasalahan dan kebutuhan keluargakeluarga di lingkungan tersebut, serta (2) Penyuluhan keluarga berperspektif gender adalah penyuluhan yang penentuan sasarannya tidak saja ditujukan bagi para istri/perempuan, melainkan juga para suami/laki-laki dan bahkan remaja putra dan putri Analisis terhadap kedua tes tersebut dapat menggambarkan perubahan nilai rata-rata pre test dan post test peserta pelatihan, sebagaimana tampak pada gambar 1 berikut. 


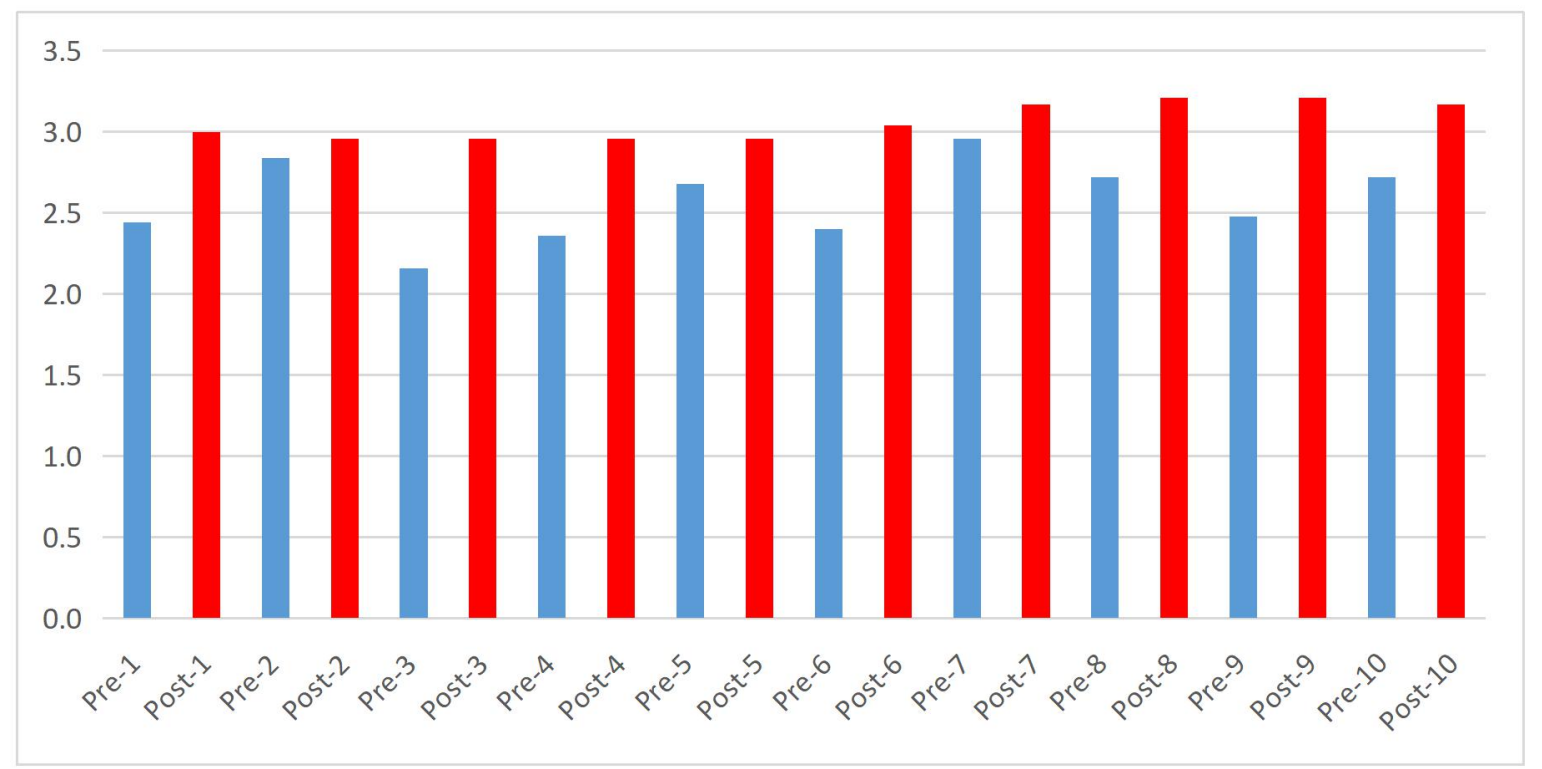

Gambar 1. Perubahan Rata-rata Nilai Pre Test dan Post Test Peserta Per Item Pertanyaan Sumber: Data Primer, Diolah

Dari Tabel 1 di atas, berikut ini dideskripsikan kondisi pengetahuan dan sikap responden pada saat sebelum dan sesudah materi berupa 10 penyataan untuk pre test maupun post. Tampak pada gambar 1 rata-rata nilai pre test maupun post test peserta di atas nilai tengahnya yaitu 2 , dengan nilai rata-rata tertinggi di atas nilai tengah adalah pernyataan nomor 7 untuk pre test, dan pernyataan nomor 7, 8, 9, dan 10 untuk post test. Sedangkan nilai rata-rata terendah di atas nilai tengah adalah pernyataan nomor 3 untuk pre test, dan pernyataan nomor 1 hingga 6 untuk post test.

Keseluruhan skor dari 10 pernyataan pada pre dan post test menunjukkan pemahaman peserta akan materi-materi yang disampaikan dalam penyuluhan. Terhadap skor tersebut, selanjutnya dikategorikan sehingga dapat diperoleh kategori pemahaman peserta sebelum dan sesudah penyuluhan, sebagaimana tampak pada tabel berikut.

\section{Kategorisasi hasil pre-test}

\begin{tabular}{|ll|r|r|r|r|}
\hline & & & & \multicolumn{1}{c|}{$\begin{array}{c}\text { Cumulative } \\
\text { Percent }\end{array}$} \\
\hline Valid & Baik & 4 & 16,0 & 16,0 & 16,0 \\
& Cukup & 21 & 84,0 & 84,0 & 100,0 \\
& Total & 25 & 100,0 & 100,0 & \\
\hline
\end{tabular}

Sumber: Data Primer, Diolah

Tampak pada tabel di atas, pemahaman peserta sebelum penyuluhan masuk kategori cukup sebanyak 21 orang dan 4 orang lainnya masuk kategori baik. Dengan demikian, sebagian besar atau 84 persen peserta relatif kurang baik atau cukup kategori pemahamannya akan tema penyuluhan.

Setelah penyuluhan, melalui post test diperoleh gambaran pemahaman peserta akan materi-materi penyuluhan. Gambaran tersebut tampak pada tabel berikut. 
Kategorisasi hasil post-test

\begin{tabular}{|ll|r|r|r|r|}
\hline & & & & \multicolumn{2}{c|}{$\begin{array}{c}\text { Cumulative } \\
\text { Percent }\end{array}$} \\
\hline Valid & & 1 & 4,0 & 4,0 & 4,0 \\
& Baik & 20 & 80,0 & 80,0 & 84,0 \\
& Cukup & 4 & 16,0 & 16,0 & 100,0 \\
& Total & 25 & 100,0 & 100,0 & \\
\hline
\end{tabular}

Sumber: Data Primer, Diolah

Tabel di atas menggambarkan perubahan pemahaman peserta setelah penyuluhan. Tampak pada tabel tersebut, ada satu orang yang tidak termasuk dalam dua kategori pada tabel. Hal tersebut disebabkan post testnya tidak dikerjakan karena yang bersangkutan ada kepentingan sehingga tidak menyelesaikan penyuluhan yang diikutinya. Selanjutnya, tampak peserta yang kategori cukup sebanyak 4 orang dan 20 orang lainnya masuk kategori baik. Dengan demikian, sebagian besar atau 80 persen peserta masuk kategori baik pemahamannya akan tema penyuluhan.

Berdasarkan gamabaran kedua tabel di atas, tampak secara kuantitatif ada perbedaan berupa peningkatan pemahaman peserta setelah mengikuti pelatihan. Guna melihat perubahan lebih mendalam pemahaman peserta, dapat dilakukan dengan analisis tabulasi silang berikut.

Kategorisasi hasil post-test * Kategorisasi hasil pre-test Crosstabulation

\begin{tabular}{|c|c|c|c|c|c|}
\hline & & & \multicolumn{2}{|c|}{ Kategorisasi hasil pre-test } & \multirow[b]{2}{*}{ Total } \\
\hline & & & Baik & Cukup & \\
\hline \multirow{12}{*}{$\begin{array}{l}\text { Kategorisasi hasil post- } \\
\text { test }\end{array}$} & & Count & 1 & 0 & 1 \\
\hline & & $\begin{array}{l}\% \text { within Kategorisasi } \\
\text { hasil post-test }\end{array}$ & $100,0 \%$ & $0,0 \%$ & $100,0 \%$ \\
\hline & & $\begin{array}{l}\% \text { within Kategorisasi } \\
\text { hasil pre-test }\end{array}$ & $25,0 \%$ & $0,0 \%$ & $4,0 \%$ \\
\hline & & $\%$ of Total & $4,0 \%$ & $0,0 \%$ & $4,0 \%$ \\
\hline & Baik & Count & 2 & 18 & 20 \\
\hline & & $\begin{array}{l}\% \text { within Kategorisasi } \\
\text { hasil post-test }\end{array}$ & $10,0 \%$ & $90,0 \%$ & $100,0 \%$ \\
\hline & & $\begin{array}{l}\% \text { within Kategorisasi } \\
\text { hasil pre-test }\end{array}$ & $50,0 \%$ & $85,7 \%$ & $80,0 \%$ \\
\hline & & $\%$ of Total & $8,0 \%$ & $72,0 \%$ & $80,0 \%$ \\
\hline & Cukup & Count & 1 & 3 & 4 \\
\hline & & $\begin{array}{l}\% \text { within Kategorisasi } \\
\text { hasil post-test }\end{array}$ & $25,0 \%$ & $75,0 \%$ & $100,0 \%$ \\
\hline & & $\begin{array}{l}\% \text { within Kategorisasi } \\
\text { hasil pre-test }\end{array}$ & $25,0 \%$ & $14,3 \%$ & $16,0 \%$ \\
\hline & & $\%$ of Total & $4,0 \%$ & $12,0 \%$ & $16,0 \%$ \\
\hline \multirow[t]{4}{*}{ Total } & & Count & 4 & 21 & 25 \\
\hline & & $\begin{array}{l}\% \text { within Kategorisasi } \\
\text { hasil post-test }\end{array}$ & $16,0 \%$ & $84,0 \%$ & $100,0 \%$ \\
\hline & & $\begin{array}{l}\% \text { within Kategorisasi } \\
\text { hasil pre-test }\end{array}$ & $100,0 \%$ & $100,0 \%$ & $100,0 \%$ \\
\hline & & $\%$ of Total & $16,0 \%$ & $84,0 \%$ & $100,0 \%$ \\
\hline
\end{tabular}

Sumber: Data Primer, Diolah

Tabel silang di atas menggambarkan, dari 25 peserta yang mengikuti pre test, sebagian besar (21 orang atau 84 persen) masuk kategori cukup, sedangkan 4 orang lainnya (16 persen) masuk kategori baik pemahamannya. Dari 16 orang yang masuk kategori cukup 
pemahamannya sebelum pelatihan, 3 orang (14,3 persen) di antaranya tetap pada kondisi yang sama, dan 18 orang (85,7 persen) meningkat menjadi baik pemahamannya. Sementara, dari 4 orang yang sebelum penyuluhan masuk kategori baik pemahamannya, 2 orang (50 persen) tetap pada kondisi yang sama, 1 orang yang menjadi tidak terkategorikan karena tidak mengerjakan post testnya, sedangkan 1 orang ( 25 persen) yang justru turun menjadi cukup tingkat pemahamannya. Dengan demikian, dari 21 orang yang masuk kategori cukup sebelum penyuluhan, turun menjadi 4 orang setelah penyuluhan. Sementara itu, 4 (empat) orang yang masuk kategori baik sebelum penyuluhan, meningkat menjadi 20 orang setelah penyuluhan.

Gambaran yang diperoleh berdasarkan tabulasi silang di atas menunjukkan kecenderungan perubahan pemahaman peserta sebelum dan setelah mengikuti penyuluhan. Guna meningkatkan kekuatan pengambilan kesimpulan atas perubahan tersebut, dilakukan dengan teknik statistika inferensial yakni menggunakan teknik chi-square, sebagaimana tampak pada tabel berikut.

Chi-Square Tests

\begin{tabular}{|l|r|r|r|}
\hline & Value & df & \multicolumn{1}{c|}{$\begin{array}{c}\text { Asymp. Sig. } \\
\text { (2-sided) }\end{array}$} \\
\hline Pearson Chi-Square & $6,027^{\text {a }}$ & 2 &, 049 \\
Likelihood Ratio & 4,481 & & 2 \\
N of Valid Cases & 25 & &, 106 \\
\hline
\end{tabular}

a. 5 cells $(83,3 \%)$ have expected count less than 5 . The minimum expected count is 16 .

Sumber: Data Primer, Diolah

Tampak pada tabel chi-square test di atas, nilai chi-squarenya sebesar 6,027. Guna mengambil kesimpulan apakah ada perbedaan pemahaman peserta sebelum dan setelah mengikuti penyuluhan, dapat dilihat pada kolom Asymp. Sig di mana jika nilai pada kolom tersebut dan baris Pearson Chi-Square $<$ dari $\alpha$ yang besarnya 0,05 maka dapat disimpulkan ada perbedaan pemahaman peserta sebelum dan setelah mengikuti penyuluhan, dan sebaliknya jika nilainya $\geq \alpha$ yang besarnya 0,05 , Oleh karena $0,049<$ dibandingkan $\alpha(0,05)$ maka dapat disimpulkan ada perbedaan pemahaman peserta sebelum dan setelah mengikuti penyuluhan. Dengan demikian, Penyuluhan Ketahanan Keluarga Berbasis Komunitas Berperspektif Gender dapat dinyatakan berhasil.

\section{KESIMPULAN}

Dari analisis data yang dilakukan dapat disimpulkan bahwa:

1. Proses pelatihan telah memberikan dampak positif kenaikan pemahaman para peserta tentang penyuluhan ketahanan keluarga yang tampak dari adanya peningkatan nilai berkategori "tahu" dari pre-test ke post-test. Hal ini diperkuat dari hasil uji beda yang menunjukkan adanya perbedaan antara kedua kondisi tersebut. Dari analisis faktor-faktor yang menjadi penyebab perceraian juga tampak adanya peningkatan pemahaman tentang hal tersebut. Selanjutnya, dari RTL yang diajukan juga tampak bahwa sebagian responden telah merencanakan perluasan target sasaran penyuluhannya yang tidak lagi hanya ditujukan bagi para istri/perempuan, melainkan juga kelompok suami/laki-laki baik melalui forum RW maupun Desa.

2. Dengan pembekalan tersebut, mereka diharapkan dapat menyuluhkan materi-materi yang diberikan di wilayah desa masing-masing hingga ke tingkat RT dan bahkan RW. Dengan demikian, diharapkan seluruh warga (tidak hanya para istri, melainkan para suami dan 
para tokoh-tokoh masyarakat setempat) dapat menyadari adanya fenomena penurunan keluarga, sehingga akan segera bersinergi untuk mencegah dan mengatasinya.

3. Secara khusus, perhatian perlu diberikan kepada desa-desa yang dari hasil pantauan para responden (karena tidak ada data resmi) memiliki kasus perceraian tinggi, misalnya: Desa Kutayasa. Diharapkan kegiatan pelatihan tersebut dapat dikhususkan di desa ini agar semua pengurus PKK RW dan RT di desa ini dapat lebih memahami, agar segera dapat bertindak cepat untuk mencegah dan mengatasinya.

\section{UCAPAN TERIMA KASIH}

Pelaksanaan kegiatan penyuluhan ini terselenggara atas dukungan dana BLU Universitas Jenderal Soedirman melalui Surat Keputusan Nomor: Kpts.216/UN23.14/PM.01.00/2019. Untuk itu diucapkan terima kasih. Ucapan terima kasih juga disampaikan kepada Pengurus PKK Kecamatan Sumbang, Kabupaten Banyumas yang telah bersedia bekerjasama membantu teknis pelaksanaan kegiatan ini baik dalam bentuk: penyampaian undangan bagi para peserta, penyediaan tempat kegiatan beserta perlengkapannya. Tidak lupa disampaikan terima kasih kepada Camat Kecamatan Sumbang yang juga telah membantu kesiapan teknisnya serta bersedia membuka acara ini. Dukungan beliau semakin menunjukkan penting dan dibutuhkannya kegiatan ini tidak saja bagi PKK Kecamatan Sumbang dan semua PKK Desa di wilayah Sumbang, melainkan juga bagi Kecamatan Sumbang pada umumnya.

\section{DAFTAR PUSTAKA}

BPS. Nikah, Talak dan Cerai, serta Rujuk, 2007-2016. https://www.bps.go.id/1

Badan Pusat Statistik Jawa Tengah. Provinsi Jawa Tengah dalam Angka Tahun 2018. https://jateng.bps.go.id/.

Badan Pusat Statistik Kabupaten Banyumas. Kabupaten Banyumas dalam Angka Tahun 2012. https://banyumaskab.bps.go.id/.

Badan Pusat Statistik Kabupaten Banyumas. Kabupaten Banyumas dalam Angka Tahun 2013. https://banyumaskab.bps.go.id/.

Badan Pusat Statistik Kabupaten Banyumas. Kabupaten Banyumas dalam Angka Tahun 2014. https://banyumaskab.bps.go.id/.

Badan Pusat Statistik Kabupaten Banyumas. Kabupaten Banyumas dalam Angka Tahun 2015. https://banyumaskab.bps.go.id/

Badan Pusat Statistik Kabupaten Banyumas. Kabupaten Banyumas dalam Angka Tahun 2016. https://banyumaskab.bps.go.id/

Badan Pusat Statistik Kabupaten Banyumas. Kabupaten Banyumas dalam Angka Tahun 2017. https://banyumaskab.bps.go.id/

Badan Pusat Statistik Kabupaten Banyumas. Kabupaten Banyumas dalam Angka Tahun 2018. https://banyumaskab.bps.go.id/.

J. Hardie,. Halliday and Amy Lucas, "Economic Factors and Relationship Quality Among Young Couples: Comparing Cohabitation and Marriage". J. Marriage Fam. 2010 Oct; 72(5): 1141-1154.2010.

KUA Kecamatan Sumbang. Data Mentah Perceraian di Kecamatan Sumbang Tahun 2015.

Maysam Musai, Seyede Marzieh Fatemi Abhari, Saeed Garshasebi Fakhr, Farnaz Karbalai Hassan, Fatemeh Nikbin Sedaghati \& Somayeh Miri. Divorce rate and Economic Factors in Iran. International Jourcal of Academic Research in Bussiness and Social Sciences, March 2014, Vol. 4. No. 3.Mohammadi, Seyed Mohammad Reza Ghaem \& Fariba Chavoshzadeh Tafti . Socioeconomic Factors Affecting Divorce in Islamic 
Republic of Iran (Yazd). https://ijbssnet.com/ journals/Vol_5 No 5 1_April 2014/ 25.pdf

Matondang, Armansyah. Faktor-faktor yang Menyebabkan Perceraian dalam Perkawinan. Jurnal Ilmu Pemerintahan dan Sosial Politik UMA. 2(2). 2014: 141-150.

Muchimah. 2015. Faktor-faktor Penyebab Perceraian di Kalangan Buruh Migran (Studi Kasus di Desa Banjarsari Kecamatan Nusawungu Kabupaten Cilacap. http://digilib.uinsuka.ac.id/15904/1/BAB\%20I\%2C\%20V\%2C\%20DAFTAR\%20PU STAK A.pdf.

Peraturan Pemerintah Nomor 9 Tahun 1975 (file:///C:/DOCUME 1/user/LOCALS 1/Temp/PP NO 9 1975.HTM.

PKK Semarang Kota. Visi dan Misi. http:/pkk.semarangkota.go.id

Puspita, Dyah Retna; Rin Rostikawati, Lilis SS., 2014. Model Penyuluhan KB Berbasis Gender dalam Mencegah Kekerasan dalam Rumah Tangga di Kabupaten Purbalingga. Jurnal Dinamika Hukum Vol. 3 Nomor 14 Edisi September 2014.

Puspita, Dyah Retna; Pawrtha Dharma, Rukna Idanati. Model Optimalisasi Peran Ketua Rukun Tetangga dalam Mencegah Perceraian di Kecamatan Purbalingga, Kabupaten Purbalingga. Jurnal Masyarakat, Kebudayaan dan Politik (MKP).http://ejournal.unair.ac.id/index.php/MKP/article/view/2598. FISIP Universitas Airlangga.

Puspitawati. 2013. Ketahanan dan Kesejahteraan Keluarga. http://ikk.fema.ipb.ac.id/v2/images/karyailmiah/ketahanan.pdf

Uchida E, Araki S, Murata K. "Socioeconomic factors affecting marriage, divorce and birth rates in a Japanese population". J Biosoc Sci. 1993, Oct,25(4):499-507. https://www.ncbi.nlm.nih.gov/pubmed/8227098.

UU Nomor 52 Tahun 2009 tentang Perkembangan Kependudukan dan PembangunanKeluarga.http://data.kemenkopmk.go.id/sites/default/files/22637790UU-No-52-Tahun-2009-Perkembangan-Kependudukan-Dan-PembangunanKeluarga.pdf. 
